\title{
Forest Carbon Sequestration Potential Estimation Research in China
}

\author{
Hong Li, Na Wang a,* \\ School of Management, Tianjin University of Technology, Tianjin 300384, China \\ a wangxiaoba1993@163.com \\ Corresponding author: Na Wang
}

Keywords: China, Forest Carbon Sinks, Volume Method.

\begin{abstract}
The article is based on the statistical data of forest resources in China, analyzes China's current situation of the development of forest resources. Then, using method of volume calculation of China from 2003 to 2014, amount of forest carbon sequestration, and the calculation results are analyzed. The study found that the forest carbon sinks and forest volume there is a strong correlation, increasing forest volume is the main way to increase forest carbon sink.
\end{abstract}

\section{Introduction}

Due to the rapid development of industrialization, carbon sequestration and carbon source can't balance development, the increasing atmospheric $\mathrm{CO}_{2}$ concentration, damage the global carbon cycle? Forest is $\mathrm{CO}_{2}$ storage library and buffers, can absorb and fixation $\mathrm{CO}_{2}$, with a strong carbon sink function. In 2016, the latest promulgated by the state council "much starker choices-and graver consequences-in control scheme for greenhouse gas emissions "stressed that to increase the ecosystem carbon sinks, strive to increase forest carbon sinks and reduce carbon emissions. Put forward to 2020, the forest coverage rate reached $23.04 \%$, the forest volume of 16.5 billion cubic meters and other requirements.

According to relevant data show that the forest area, though only about a third of the total land area, but the forest vegetation in terrestrial carbon reserves accounted for almost half of the total, is very important to slow down the greenhouse effect. Research on domestic and foreign scholars agree that the forest is the world recognized as the most cost-effective solution to rising $\mathrm{CO}_{2}$, therefore forest carbon sink project is being paid attention to by the international community.

\section{Forest Resource Status in China}

China is the largest country in the world of artificial afforestation area, and continue to mass in returning farmland to forest and afforestation, increase forest carbon sink. By the eighth forest census data in 2013, China's forest area and forest accumulation among the worlds fifth and sixth, respectively, plantation area is still the highest in the world. In recent years, China's forest resources present a number continues to grow, steadily improving quality, efficiency increasing good momentum. The first four to eight times the national forest census data shown in the table below:

Table 1. Forest Resources of China in 1994-2013

\begin{tabular}{|c|c|c|c|c|c|c|}
\hline Year & $\begin{array}{c}\text { Forestry land } \\
\text { area }\left(10^{4} \mathrm{hm}^{2}\right)\end{array}$ & $\begin{array}{c}\text { Forest } \\
\text { area } \\
\left(10^{4} \mathrm{hm}^{2}\right)\end{array}$ & $\begin{array}{c}\text { Plantation } \\
\text { area } \\
\left(10^{4} \mathrm{hm}^{2}\right)\end{array}$ & $\begin{array}{c}\text { Forest } \\
\text { coverage } \\
\text { rate } \\
(\%)\end{array}$ & $\begin{array}{c}\text { Dynamic total } \\
\text { volume } \\
\left(10^{4} \mathrm{~m}^{3}\right)\end{array}$ & $\begin{array}{c}\text { Forest stock } \\
\text { volume } \\
\left(10^{4} \mathrm{~m}^{3}\right)\end{array}$ \\
\hline $1994-1998$ & 26329.47 & 15894.09 & 4708.95 & 16.55 & 1248786.39 & 1126659.14 \\
\hline $1999-2003$ & 28492.56 & 17490.92 & 5364.99 & 18.21 & 1361810 & 1245584.58 \\
\hline $2004-2008$ & 30590.41 & 19545.22 & 6168.84 & 20.36 & 1491268.19 & 1372080.36 \\
\hline $2009-2013$ & 31259 & 20768.73 & 6933.38 & 21.63 & 1643280.62 & 1513729 \\
\hline
\end{tabular}


Analysis of the above data shows that China's various forest resources statistics indexes to keep continuous growth trend. However, the forest coverage rate is far lower than the global average of $31 \%$, forest area per capita is only $1 / 4$ of the world average, stored only $1 / 7$ of the world's average per capita forest, the forest resources relative insufficiency, the quality is not high, the condition of uneven distribution of still not get the fundamental change, the people expect mountains greener, waters cleaner and more livable environment more urgent, the afforestation improving ecological a long way to go.

\section{Forest Carbon Sequestration Estimation Analysis}

\subsection{Estimation Method Choice}

Consulting relevant literature, found that estimates the amount of forest carbon sinks method usually has three types: first, using meteorological technology, determine the content of forest absorb $\mathrm{CO}_{2}$; second, the sampling determination of forest biomass; third, it is through the forest inventory data, using relevant models for estimating forest carbon sinks. In the light of the data availability and real conditions, this article selects the third estimation method.

\subsection{Amount of Forest Carbon Sequestration Estimation}

Estimate the amount of forest carbon sinks model method, the most commonly used with biomass, volume and biomass listing method, etc. Biomass method is the use of common, its use is relatively convenient and clear. Volume method not only retained the biomass method directly, the advantages of convenient, also has good practical characteristics, the calculation is based on the forest volume carbon sinks, converted to biomass, multiplied by the corresponding coefficient of transformation for the amount of carbon. Biomass listing method need to master a large number of forest survey data, is relatively complicated. By comparison, this paper select operation simple and practical method of the volume of business accounting of forest carbon sinks, the specific calculation formula is as follows:

$$
\begin{aligned}
& C_{f}=s \times c+\alpha(s \times c)+\beta(s \times c) \\
& c=v \times \delta \times \rho \times \gamma
\end{aligned}
$$

Formula of the symbolic meaning is as follows: $\mathrm{C}_{\mathrm{f}}$ : carbon sequestration of forest; $\mathrm{s}$ : forest area; $\mathrm{c}$ : forest carbon density; $v$ : forest volume per unit area; $\alpha$ value is 0.195 , the carbon conversion coefficient of undergrowth; $\beta$ value 1.244, forest low carbon conversion coefficient; $\delta$ value 1.9 , biomass expansion coefficient; $\rho$ value 0.5 , volumetric coefficient; $\gamma$ value of 0.5 commonly, carbon content.

On the basis of "Chinese forestry statistical yearbook", "China statistical yearbook" forest resources data and related research report, application of the calculation formula of calculating the amount of forest carbon sinks, the results are shown in table 2 as follows:

\begin{tabular}{|c|c|c|c|c|c|}
\hline Year & $\begin{array}{c}\text { Forest area } \\
\left(10^{4} \mathrm{hm}^{2}\right)\end{array}$ & $\begin{array}{l}\text { Forest stock } \\
\text { volume } \\
\left(10^{4} \mathrm{~m}^{3}\right)\end{array}$ & $\begin{array}{c}\text { Volume per unit } \\
\text { area } \\
\left(\mathrm{m}^{3} / \mathrm{hm}^{2}\right)\end{array}$ & 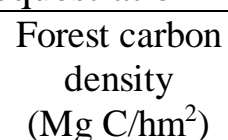 & $\begin{array}{c}\text { The forest carbon } \\
\text { sequestration of } \\
\left(10^{4} \mathrm{TgC}\right)\end{array}$ \\
\hline 2003 & 15894.09 & 1126659.146 & 70.89 & 33.67 & 2747921.66 \\
\hline 2004 & 17490.92 & 1245584.58 & 71.21 & 33.83 & 3037980.79 \\
\hline 2005 & 17490.92 & 1245584.58 & 71.21 & 33.83 & 3037980.79 \\
\hline 2006 & 17490.92 & 1245584.58 & 71.21 & 33.83 & 3037980.79 \\
\hline 2007 & 17490.92 & 1245584.58 & 71.21 & 33.83 & 3037980.79 \\
\hline 2008 & 17490.92 & 1245584.58 & 71.21 & 33.83 & 3037980.79 \\
\hline 2009 & 19545.22 & 1372080.36 & 70.20 & 33.35 & 3346504.00 \\
\hline 2010 & 19545.22 & 1372080.36 & 70.20 & 33.35 & 3346504.00 \\
\hline 2011 & 19545.22 & 1372080.36 & 70.20 & 33.35 & 3346504.00 \\
\hline 2012 & 19545.22 & 1372080.36 & 70.20 & 33.35 & 3346504.00 \\
\hline 2013 & 20768.73 & 1513729.72 & 72.89 & 34.62 & 3691986.79 \\
\hline 2014 & 20768.73 & 1513729.72 & 72.89 & 34.62 & 3691986.79 \\
\hline
\end{tabular}

Table 2. Estimates of Forest Carbon Sequestration in China

By table 2 shows that China's amount of forest carbon sinks gradually increased from 27.4792166 
billion tons in 2003 to 2014, 36.9198679 billion tons, the absolute growth of less than 2003 half; Combined with the status quo of China's marginal carbon emissions, China's low carbon development situation is not optimistic. The reason is that China is continuing to achieve forest resources development goals at the same time, also exists some problems that cannot be ignored. 2014 years of Chinese forest area is 207.6873 million hectares, the forest volume is 15.1372972 billion cubic meters, the forest coverage rate is $21.63 \%$, the forest coverage rate is lower than the world average level of developed countries, and the forest quality is low, volume per area of forest only about $69 \%$ of the world's average level. At the same time, as China's industrialization and urbanization level increase, the demand for forest resources, excessive deforestation is often happened in great quantities, unreasonable exploitation in such a way that our country forest area of slow growth. As a result, China's relatively slow growth of forest carbon sequestration of forest carbon sequestration of carbon sequestration effect is relatively limited.

Further analysis found that the 2004-2008, 2008-2012 and 2013-2012, three times the amount of forest carbon sequestration were maintained at 30.3798079 billion tons, 33.46504 billion tons and 33.46504 billion tons, at the same time of forest volume at 12.4558458 billion cubic meters and 12.4558458 billion cubic meters and 12.4558458 billion cubic meters; Shows that the forest carbon sequestration of main volume and the forest there is a strong correlation, increasing forest volume is the main way to increase forest carbon sink. In addition, between 2003 and 2014, the amount of forest area and forest carbon sinks are keep growth trend, expanding forest area to a certain extent will promote the growth of the amount of carbon sink.

\section{Conclusion}

To further improve the ability of carbon sequestration of forest resources in China, it is necessary to continue expanding forest area, improve the quality of the forest. To protect native forest ecosystems are not destroyed, restore degraded forest ecosystem; Change the original "afforestation, light weight cradle" way of forestry, establishing new forest ecological system, at the same time, improve the operation and management level, forest resources are the effective ways to enlarge the forest carbon sinks. The development of Chinese forestry carbon sequestration potential is tremendous, forest area, volume, improve forest coverage would mean the improvement of forest carbon sequestration capacity. Believe that with the improvement of quality of China's forests, forest carbon sinks function will play a greater role to China's social and economic development.

\section{References}

[1]. Shaohua Yin, Wenpeng Zhou. Estimation and evaluation of Hunan forest carbon sinks. [J]. Journal of Central South University of Forestry \& Technology, 2013, (7): 136-139 + 144.

[2]. Xiaofen Yin, Jason, Xiaoming Wang. Current Status of Forest Carbon Sinks in Guizhou Province and Their Increasing Potential. [J]. Journal of Earth and Environment, 2012, (02): 266-270.

[3]. Fangxiao Dong .Analysis of Estimation Forest Carbon Sequestration in China-A Case Study of Forest Resources in Liaoning Province. [J]. Journal of Forestry Economy, 2010, (9): 54-57.

[4]. Guanlong Gao, Xiaoyou Zhang. Carbon Emissions Present Situation and the Analysis of theImportance of Forest Carbon Sinks in the Inner Mongolia Autonomous Region. [J]. China Population, Resources and Environment, 2014, (S2): 24-27.

[5]. Songjun $\mathrm{Xu}$, Liangyu Li, Yan Zhao,et al.China forestry carbon sequestration research progress [J]. Journal of Guangdong Agricultural Science, 2014, (4): 218-222.

[6]. Ligong Xie, Hongtao Zhang. Forest Carbon Sequestration Assessment and Potential Analysis in Heilongjiang Province [J]. Journal of Territory \& Natural Resources Study, 2011, (4) : 88-89. 